DOI: https://doi.org/10.30749/2177-8337.v24n49p11-12

\title{
MENSAGEM DOS DIRIGENTES
}

Nesta edição, a Revista da Seção Judiciária do Rio de Janeiro, SJRJ, publica artigos, cujas temáticas foram apresentadas no II Seminário de Direitos Humanos: em Tempos de Pandemia, organizado pelo Centro Cultural Justiça Federal, CCJF.

Além dos textos com as abordagens do evento de direitos humanos, o periódico recebeu também artigos com reflexões importantes como Legislações sobre Aborto e o Direito à Saúde da Mulher; Os Impasses Socioambientais Oriundos da Mineração na Colômbia: um olhar diante do desenvolvimento sustentável e do estado de direito ambiental; Vulnerabilidade Socioambiental e Qualidade de Vida de Mulheres do Município de Duque de Caxias/RJ.

Os artigos Empregadas Domésticas Negras no Cenário da Pandemia: aspectos sobre a vulnerabilidade; Reflexos do Machismo Estrutural Brasileiro em Tempos de Covid-19: quando o distanciamento social é tão letal quanto o vírus; A Pandemia do Coronavírus e os Grupos Vulneráveis: uma análise quanto à eficácia dos atos do governo brasileiro; A Dificuldade do Acesso à Saúde pelo Grupo LGBTI no Brasil durante a Pandemia: uma análise à luz da teoria da eficácia horizontal dos direitos humanos; Controle Judicial das Políticas Públicas e Necropolítica no Rio de Janeiro em Tempos de Covid-19; El Covid-19 y La Crisis Carcelaria en Tiempos de Pandemia: una perspectiva desde el panorama penitenciario en Brasil e O Sistema de Processamento Eletrônico da Justiça Federal da 2a Região e o Direito Fundamental de Acesso do Cidadão à Justiça em Tempos de Pandemia expressam as preocupações das pessoas em geral e 
também dos pesquisadores com a problemática gerada pela pandemia do novo coronavírus e também com a doença propriamente dita.

O TRF2 e a Seção Judiciária do Rio de Janeiro e Espírito Santo vêm cumprindo todas as medidas sanitárias para preservar a saúde dos jurisdicionados, advogados, servidores e magistrados, sem perder a continuidade da prestação jurisdicional, adotando o trabalho remoto desde meados do mês de março.

Acreditamos que nossos periódicos acadêmico-científicos constituem mais uma iniciativa de aproximar o Judiciário Federal com os pesquisadores que pensam o Direito e a Justiça, sendo um canal aberto para os acadêmicos, pesquisadores e alunos da pós-graduação strictu senso publicarem seus trabalhos.

Na presente edição da Revista da Seção Judiciária do Rio de Janeiro, oferecemos ao leitor, além de estudos importantes sobre os direitos humanos. Esperamos que, com essa publicação, estejamos contribuindo para discussões teóricas importantes em um momento tão sensível à realidade do Brasil e do mundo.

Reis Friede

Messod Azulay Neto Osair Victor de Oliveira Jr. 